doi:

\title{
Discovering factors influencing study success of students with disabilities and learning difficulties in an interview study
}

\author{
Hrabéczy Anett
}

Debreceni Egyetem Bölcsészettudományi Kar Nevelés- és Művelődéstudományi Intézet

\begin{tabular}{|c|c|}
\hline INFO & ABSTRACT \\
\hline $\begin{array}{l}\text { Hrabéczy Anett } \\
\text { hrabeczyanett@gmail.com }\end{array}$ & $\begin{array}{l}\text { Abstract. The focus of our research is on students with } \\
\text { disabilities defined by the current National Higher Education }\end{array}$ \\
\hline $\begin{array}{l}\text { Keywords } \\
\text { higher education, drop } \\
\text { out, disabilities, success }\end{array}$ & $\begin{array}{l}\text { millennium, due to the expansion of higher education, the } \\
\text { above-mentioned students appeared at universities, but } \\
\text { regulations dealing with their presence in Hungary were laid } \\
\text { down as late as } 2007 \text {. Earlier researches have studied the } \\
\text { accessibility and inclusive practices of the institutions } \\
\text { internationally and in Hungary, but only little attention has } \\
\text { been paid to these students' chances of acquisition and } \\
\text { retention to higher education. Equal opportunities in higher } \\
\text { education appear to be an important supporting factor in our } \\
\text { research however, the overall social context of the individual } \\
\text { has a great influence on successful entry and graduation. A } \\
\text { further research opportunity, a deeper, more extensive } \\
\text { quantitative study of the institutional presence of students } \\
\text { with disabilities and the factors contributing to their learning } \\
\text { success is emerging. }\end{array}$ \\
\hline
\end{tabular}

Kulcsszavak
felsőoktatás,
lemorzsolódás, sajátos
nevelési igény,
eredményesség

Sajátos nevelési igényü hallgatók tanulmányi
eredményességét befolyásoló tényezők feltárása egy
interjús kutatás tükrében. Kutatásunk középpontjában
azok a hallgatók állnak, akiket a hatályos felsőoktatási
törvény fogyatékossággal élö hallgatónak nevez. A téma
aktualitását adja, hogy a felsőoktatási expanzió
következtében az ezredforduló után nagyobb számban
jelentek meg az említett hallgatók az egyetemeken, azonban
jogszabályi szinten csak 2007 óta foglalkoznak
jelenlétükkel. A korábbi kutatások nemzetközi és hazai
viszonylatban is vizsgálták az intézmények
akadálymentességét és inkluzív gyakorlatait, kevés
figyelmet fordítottak azonban a bekerülési és bennmaradási
esélyekre. Legfontosabb eredményeink alapján lényeges




\begin{abstract}
támogató faktorként jelennek meg a felsőoktatásban megvalósuló esélyegyenlöségi támogatások, azonban a sikeres bekerülést és a diplomaszerzést nagy mértékben képes befolyásolni az egyén konkrét társas kontextusa. További kutatási lehetőségként felmerül a fogyatékossággal élö hallgatók intézményi jelenlétének és tanulmányi eredményességet támogató tényezőinek mélyebb, szélesebb körü kvantitatív vizsgálata.
\end{abstract}

Ez a tanulmány a 123847 számú projekt a Nemzeti Kutatási Fejlesztési és Innovációs Alapból biztosított támogatással, a K_17 pályázati program finanszírozásában valósult meg.

\title{
Introduction
}

Due to the expansion in higher education in the nineties, non-traditional students appeared at universities (Attewell és mtsai, 2007; Harper és Quaye, 2009; Pusztai, 2011, Fenyves és mtsai., 2017). Regarding non-traditional students, the Hungarian literature often examines non-full-time students, while in the international literature mostly students from the unconventional social classes are listed here (but in many cases these two categories may be mixed and their interpretation may vary from context to context). (Tözsér, 2012). According to international researches, the nontraditional student term includes: students from low-status families, first-generation university students (whose parents did not go to university), women, parents, students who are members of an ethnic group, students of different religions, students who are older than average university students, who are learning and working at the same time, and the students with special needs or disabilities, learning difficulties (Pusztai és Szabó, 2014; Tözsér, 2012). Students mentioned above have a greater risk of dropping out of university therefore higher education cannot perform effectively its task to reduce inequalities in society (Fenyves és mtsai, 2017).

Hungarian literature knows very little about the situation of students with disabilities at universities (Bánfalvy, 2014), only a few studies have been carried out in this area. However, we know that the number of students with disabilities has been increasing in higher education, yet they have lower qualifications than the average population (KSH, 2011). Of students with disabilities, fewer of them appear in higher education, this will further undermine their chances in finding jobs (Fogyatékosságügyi statisztikák 2009).

In recent years, however, it has been observed that people with disabilities have higher levels of education, and more and more people graduate and obtain a university degree (Laki, 2017). While in 2001, 5.2\% of people with disabilities had a degree, in 2011 this ratio increased to $9 \%(\mathrm{KSH}, 2011)$. With the improvement of qualifications, it can be observed that the situation of people with disabilities in the labour market also improved. KSH conducted a micro census in 2016, and based on the results of the micro census, $3 \%$ more people with disabilities were found in the labour market. This proportion could further improve if more people with 
disabilities successfully completed university. It is therefore necessary to make higher education more accessible to them, since their labour market situation is likely to improve as their qualification increases (Laki, 2017).

\section{Disabilities and learning difficulties in higher education}

The concept of special educational needs in Hungary and internationally

In Hungary, the situation of students with special educational needs in public education institutions is regulated by the Act CXC of 2011 on National Public Education. This Act defines a major group called „students with special attention”. Within this we can distinguish two subgroups, „children requiring special treatment" and „socially disadvantaged children”. Within the ,children requiring special treatment", three categories can be distinguished: students with special educational needs, students with learning and behavioural difficulties and the highly talented students.

The OECD definition differs in some ways; there are some differences in the names of the categories. While in Hungary the special educational needs category is a separate group within the framework of special treatment, in the definition developed by the OECD, the Special Educational Needs (SEN) constitute of a collective concept of pupils with special attention (Csányi, 2007). According to the OECD, the special educational need is the name of a larger group of people with disabilities, people with learning difficulties (such as dyslexia, dysgraphy, etc.) and disadvantaged students (which is representing a wider category than the Hungarian definition, including social, cultural and linguistic factors).

The definition of special educational needs in the Hungarian educational system In the Act on National Public Education, the definition of special educational needs is as follows: someone who is struggling with mobility impairment, who is visually impaired, hearing impaired, mentally handicapped, speech-impaired, cumulatively disabled, or identified with autism spectrum disorder or other psychological development disorders (serious learning disorder like dyslexia, dysgraphia, dyscalculia, attention or behavioural disorder).

In our research, we use the phrase ,students with disabilities and learning difficulties" which is the same as the Hungarian special educational needs group, and includes two groups from the OECD definition (people with disabilities, and people with learning difficulties).

According to Mesterházi (2006), the current Act on National Public Education describes the concept of special educational needs as a non-diagnostic category, but as a collective term that provides extra rights, so the focus of this concept is on schooling. This attitude and concept have been present in Hungary since 2003 (Gordosné, 2004). Gordosné understands that a student with special educational needs can only meet the school requirements with some extra service and help. 


\section{Students with disabilities in higher education in Hungary}

The Act on National Higher Education and the Act on National Public Education differently define students with special educational needs. The Act on Higher Education does not use the concept of ,children requiring special treatment”, but uses ,students with disabilities" as an independent generic term (and using this term instead of a pupil with special educational needs).

Students with disabilities first appeared in higher education in the academic year of 2002-2003 (Laki, 2015), and while their proportion in higher education has been increasing, they are still a very small part of the students, and only $9 \%$ of the total population with disabilities have a degree according to the KSH 2011 census data.

The distribution of students with disabilities on the basis of EUROSTUDENT V's results in Hungary is as follows: there is no correlation between the level of university education and the hours of the courses (day time or evening), but there is a slight variation in from which they get a degree in (Kiss, 2014). The number of students with disabilities and learning difficulties is slightly overrepresented in the fields of social sciences and liberal arts, while their number in the fields of economics, sports sciences, information technology and law is slightly underrepresented (Kiss, 2014). This is somewhat contradicted by Bódi and Garai's research in 2011. The research found five courses that were the most popular among students with disabilities including IT and engineering, although in Bódi and Garai's research the responses from disabled students only were examined, and the role of students with chronic illnesses is investigated only in the EUROSTUDENT study. (Bódi és Garai, 2011).

\section{Equal opportunities in Hungarian higher education}

One of the key components of the realization of equal opportunities is how the institution sees different student groups. As social norms and inclusive attitudes changed over time, higher education institutions began to open up to disadvantaged students (Pusztai és Szabó, 2014). Gabriella Pusztai and Diána Szabó examined this question in 2014, approaching the direction of higher education students. The aim of the study was to find out how students are related to students with disabilities. Among the difficulties it highlights the low level of preparedness of the institutions to educate and accommodate students with disabilities, most evidently in the methodological preparedness of the instructors, and they have found that there is a significant negative attitude towards disabled students. The conclusion is that the current teaching practice can be a significant obstacle to the learning process of students with disabilities throughout their university years (Pusztai és Szabó id.: Tinklin és mtsai. 2004; Fuller és mtsai. 2004).

Holloway (2001) and Fuller (2004) approach the question from the view of disadvantaged students. Holloway conducted a research in 2001 in which 6 students with disabilities participated. Holloway explored what disabled students' experiences were about the institutional infrastructure and the accessibility of institutional services. One of the major results of the study is that institutions have resolved a significant part of the challenging problems in an online environment. However, employees from different units in universities have different attitudes, and universities are facing a long-term challenge of rethinking how to evaluate the 
performance of disabled students (Pusztai és Szabó, 2014). Holloway (2001) points out that the inclusive environment alone does not eliminate negative discrimination and marginalization, therefore several components have to function in order to achieve equal opportunities (Pusztai és Szabó, 2014).

Fuller conducted a research in 2004 which analyzed the obstacles faced by students with learning disabilities. It highlights that just around $10 \%$ of students with disabilities indicate their disability and their need for extra services. More than half of the participating students had encountered learning or management problems coming from their barriers, but students who hid their disability were even less assisted and faced more problems. According to the most important conclusions of Fuller (2004), the results show that disabled students think that their difficulties have an impact on their chances in higher education and they think that higher education is not an open environment, as opposed to the opinion of non-disabled students (Pusztai és Szabó, 2014).

Similarly, EUROSTUDENT V. examines comparable results for Hungarian students as described in Holloway (2001) and Fuller (2004). According to László Kiss (2014), EUROSTUDENT V results showed that students with disabilities are less satisfied with institutions' services, learning opportunities and the atmosphere than the average of the total respondent sample, however, there are differences in the satisfaction of people with different types of disabilities (Kiss, 2014).

In Hungary, efforts to ensure equality of opportunity for students can be found at several points in the Higher Education Act, ministerial decrees, and regulations of the institutions. Among others, for example, when applying for admission to higher education, candidates with disability receive extra points from 2008 on (Dávid, 2015). This type of positive discrimination is applied to other groups like for example disadvantaged students and, according to the writing by Zsófia Kálmán and György Könczei (2002), they are sometimes regarded as unfair by other parts of the society. According to Vida (2017), this can be observed in the field of education as well. It draws attention to the situation (especially in the case of learning difficulties) when certain secondary and higher education institutions reject students with disabilities. Vida (2017) explains that there is no competency measurement for students with disabilities, and, in the absence of such (especially in the field of public education), the institution cannot find out about the individual's level of skill. In the case of higher education, Vida reports, that certain faculties such as education and medical studies exclude students with disabilities. In contrast with this statement, the result of a second analysis of a 2015 study (IESA) database shows that there are disabled students in teacher training.

\section{Pursuing equal opportunities in the light of the Act on National Higher Education}

To promote equal opportunities for students with disabilities, the Higher Education Act covers a number of points. Article 20 describes in detail, by types of disability, the various services and their extent that can be offered to students. However, the Act defines that they cannot be exempted from basic education requirements. Article 20 provides equal opportunities for students with various types of disabilities as follows: if disability justified, the student can apply for partial or total exemption from the practical requirements, the student can shift a written exam with an oral 
exam and vice versa, the student can be wholly or partially exempted from taking the necessary language exam. In some cases it suggests providing special tools and fixtures, and providing personal assistants during the lessons. In all cases, it emphasizes that longer preparation time is needed for students with disabilities compared to the other students, which means to prolong test taking time by $30 \%$. In the case of ADHD, behavioural disorder, and autism spectrum disorder, it provides the opportunity to minimize waiting time for an exam, to separate them from other students or to have multiple exams for one subject. The act defines the services that can be given for each type of disability, and it also provides the opportunity to apply for services other than those included in it, however, this may vary from university to university in practice, furthermore this may help other students with disabilities, including chronic illnesses.

\section{The research}

\section{The purpose of the research}

The purpose of the research is to examine factors affecting entry and retention in higher education from the viewpoint of students with disabilities, based on the following criteria:

- The perception of students with disabilities about the higher education institution they attend and about the effectiveness of equal opportunities and services offered to them.

- Identifying factors affecting students with disabilities that have a negative impact on their academic years, their academic achievement, their graduation, and searching for solutions to them using the experience of the students with disabilities.

- Examining the academic life of students with disabilities, exploring the relationship and interaction between academic effectiveness and equal opportunities at institutional level.

- Also, when examining the academic life of students with disabilities, they explore the attitudes of their families, their relation to learning, and their influence on the academic life of students with disabilities.

- Examining to what extent the possibility of equal opportunities to get into the higher education can be provided for the students and their families prior to applying for a higher educational institution, and how this affects the entry into higher education and the academic period in higher education.

\section{Research questions:}

- What are the difficulties faced by students with disabilities in higher education regarding the practice of equal opportunities?

- Do these difficulties influence the educational effectiveness and motivation of students with disabilities?

- Does equal opportunity in higher education affect the career choice of students with disabilities? 


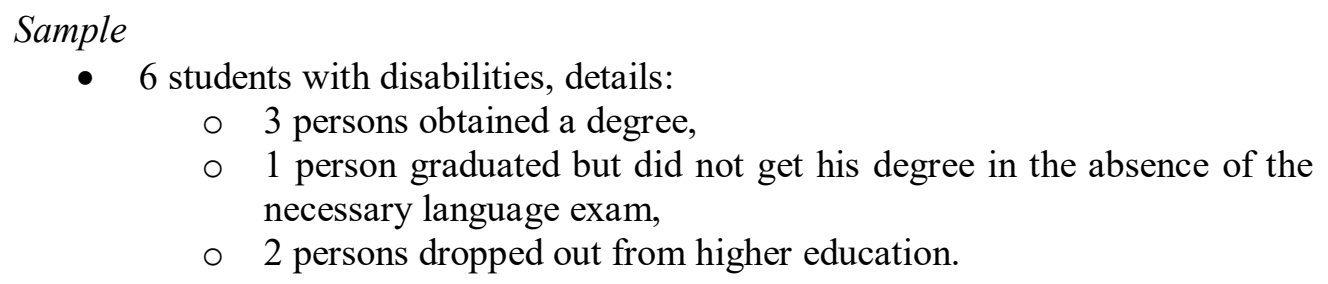

\section{Methods}

The research involves a semi-structured interviews scan. The interviewees were selected by snowball method.

\section{Results}

In the semi-structured interview study 6 persons participated, including 4 women and 2 men. Four of them were diagnosed with dyslexia, one of them with dyscalculia, while one of them was hearing impaired. However, when applying for higher education, not all of them applied for the obtainable extra points (they were among those who used the opportunity to earn extra points for a higher level diploma).

Although the distribution of disabilities is disproportionate, each interview can provide us with important lessons that can lead us closer to understanding the issue of students with disabilities.

The questions of the interview can be divided into different dimensions. Questions about the relationship of the family with learning and their attitude to the studies of the individual are included in the first round. After that we asked about the study life of the interviewees, encompassing their experience in elementary, high school and higher education, and their experience about teachers and students depending on school, as well as their difficulties in school life. We also asked them about finishing their studies, their experience while studying, how they manage after, and what future plans they have.

When analyzing the answers received, a number of critical points were revealed that greatly influenced the respondents' academic life and attitude. Therefore, when analyzing the results, we did not analyze the interviews in accordance with the dimension of interview questions, but rather the resulting nodes, which are as follows.

The first node is the realization of the problem and its circumstances, especially when and how it was noticed (which is especially interesting for people with learning difficulties without apparent external sign of the problem, and which are most likely to appear in school years). Then, as a result of the discovery, how the family's relationship to learning developed and whether the pupil was provided the right development in time. An important factor is the people who know about the student's problem (typically teachers and fellow students), and also what their attitude towards the student is like. We received important information about the impact of the surrounding environment on motivation. The environment also includes the influence of family, friends and teachers. The influence of career orientation, the attitude 
towards the success of the student with disabilities, and the role of motivation for further education have played a significant role, even if the student does not feel able to enter higher education. As an important factor, the students' confidence in their ability and its impact on their career choice has emerged. It was important to see whether the students had asked for help, and if so, who they turned to when these problems emerged during their education. Students tended to turn to fellow students, instructors and assisting organizations. In this matter, it was important for the student to have information on various forms of help request, and whether the requested assistance was provided in the particular case. In addition to help request, their own strategies aimed at facilitating school / university life, learning methods and their effectiveness in the studies have played a prominent role. The nodes of the post-study period include whether the learner is willing / able to find a job according to their qualification, and whether they are satisfied with it or looking for another job.

\section{Identifying the problem and the subsequent period}

For students with disabilities, when it comes to learning outcomes and career, it is of the utmost importance when they identify their disability or/and learning difficulties, and when the problem causes serious obstacle for the individual for the first time. It is important to ask who noticed the problem and when and whether the individual received appropriate and targeted development after the discovery, and how the expectations of the parents and the environment have changed about the learning outcomes. For six of our interviewees, the following can be observed: the problem of the hearing impaired interviewee soon became apparent, mentioning hearing loss due to medical malpractice. She then received speech therapy for half a year at the end of kindergarten. Four of our interviewees - including two of them with dyslexia - were diagnosed in the early years of the primary school and one was associated with severe dysgraphia. Each of them reported that a teacher recognized the problem. Our respondent with dyscalculia found out about his problem in the secondary school only. During his school career, his results in mathematics gradually deteriorated. As he approached graduation, he had significant difficulties. After the series of failures, teachers asked the family to contact an expert. Therefore, it is clear that teachers can play an important role in recognizing the need for special education during the school period as they see the children in different learning situations. In addition to the role of teachers, the role of parents is equally important. In the case of our interviewees, where the problem was discovered in time, parents also tried to provide them with the right development that helped them to continue on with their studies smoothly. Besides development, the parents' expectations towards the children's achievements also changed. According to our interviewees, the parents, even though they lowered their expectations for short-term goals such as end-of-year certificates, their long-term goals still included their child should enrol in higher education and graduate in the child's interest and in line with his abilities.

In this respect, another important factor is who knows about the difficulty in the environment of the individual. For all respondents, it could be observed that a large proportion of the environment in primary and secondary schools (other students and school staff) knows about their disabilities and can provide help. From that point on they were accepted by the school community and they did not feel left out. However, 
entering into higher education changed the situation. The respondents reported that they were talking about their difficulties with very close friends only, and they tried to avoid telling their instructors about it unless it was absolutely necessary, which resulted in many difficulties and misunderstanding. Except for the hearing impaired person - who talked to a single instructor about her problem - none of them spoke about their case with their instructors, so they did not get help with lessons or exams. However, the teacher that knew about the problem actively helped and provided the necessary help.

\section{Motivation}

Looking at the issue of motivation, the motivational role of the environment became obvious during the interviews alongside with the internal motivation of the individuals. During the interviews it became clear that motivation of the environment included support from the family and teachers, and if they suggested a suitable carrier that affected the career choice of individuals. In the case of our interviewees, the role of friends on this issue did not emerge prominently.

All of the interviewees reported that their families still had expectations on their learning outcomes, but motivating them got less attention. In contrast with this, the incentive effect of the instructors was particularly prominent in all of them. The role of teachers in choosing career was also decisive. In the case of one of our interviewees, the teachers recommended her a carrier and corresponding higher education which resulted in her applying for the suggested faculty. For our other interviewee, the picture is more complex, the instructors encouraged her to enrol in higher education but suggested an area that did not fit into her long-term goals, so she chose another course. After making a decision, her teachers continued to support and agreed with her choice. In her case, it was also remarkable to what extent her teachers and family trusted in her success. We should also mention our next interviewee who did not want to enrol in higher education, nevertheless the interviewee applied for his teachers' sake.

Self-evaluation is part of the internal motivation and it also influences career choice. For one of our interviewees, this was the following:

"In primary school, I decided to go to college after graduation, because I wanted to prove that my learning difficulty did not affect me, and I did not want to get the "silly title". In secondary school, this decision was further strengthened by my community; I wanted to be intellectual, and I did not want to get stock at the level of others." (25-year-old woman with dyslexia)

Similarly, the case of our other interviewee:

"After school, I went to work as a labourer and I was doing the worst job. There I decided that I did not want to do this until the end of my life and because I successfully graduated, I thought I would try to enrol in higher education." (28-yearold man with dyslexia)

Before choosing their course, each of them considered their own skills and interests and tried to choose accordingly. Several of our subjects reported that their perception of their own abilities influenced their career choices. One of them wanted to be a doctor, but because of her hearing problems, she decided to find another but still similar career. Then she chose biology. She was disappointed with the training, 
but she did the course. After getting her degree, she completed massage training and started her own business. According to her, she found the profession closest to her original ideas, and she can enjoy it and do it successfully.

Our next interviewee wanted to apply for special education, but she did not think that she could be successful in getting into the course, so she chose social pedagogy. Later she regretted it, and always considers her original plan as a missed opportunity.

\section{Managing in the educational system}

The following factors played a part in the interviewees' school life. Did the students ask for help from students / trainers / help organizations, if so, in what cases? Were they aware of the different forms of assistance and available opportunities? Did they themselves develop any strategies to facilitate institutional life?

For all of our interviewees the different forms of help in primary and secondary school were a lot more easily accessible than in higher education. Thus, it shows that there are differences not only in the use of concepts in the Acts on National Public Education and on Higher Education but also the students themselves found a lot of differences during their studies. Typically, interviewees most frequently asked for assistance from other students, with notes, book sharing, administration or studying together for an easier understanding. They did not ask for help from their teachers, and only one of them reported on the difficulties to one teacher. Only two of the interviewees a university-run organization to help in acquiring the necessary language exam, and one of them asked for permission to substitute a course. According to the respondents' comments, they had no information about who they could turn to or what opportunities they were offered to facilitate them. The information on how to substitute a course was found when the student had already been in a year behind, so the lack of information strongly hindered her in her studies.

Typically, the interviewees did not have their own strategies to facilitate their studies. Based on their statements, they were not prepared for the challenges of higher education; they found the amount and complexity of the curriculum a lot more difficult than expected. Three of the subjects increased the time spent on studying, while one of them tried to sit in the front row during every lesson to see and hear the lecture well and often relied on friends' help with their notes. There seems to be some connection between the development of learning strategies and the love for learning, since students who did not like to study, by their own admission, did not attempt to change their learning methods, while those who sought to facilitate learning, reported that they had learned to like studying and would like to continue on with it.

\section{Period after completion of studies}

As mentioned at the beginning of the analysis of the interviews, 3 of our respondents got their degree, one of them passed the final exam, but in the absence of the necessary language exam, she did not get her degree, and two of them dropped out.

We also received relevant information from the interviewees about the period following the completion of their studies. During the interviews, they also talked about how motivated they were in getting a degree. If they did, they would get a job 
in that field or chose a different career; or whether they were planning to go back to study later in life.

Three of our respondents said that they were in line with the curriculum, but one of them wanted to change course later, and would like to learn a profession that is not related to the gained knowledge so far. One of them, after getting the bachelor, learned a new profession in the following academic year and started working in that field. Regarding the two dropped-out interviewees, they said that if they found a course that matched their interest and skills, they would enrol to it.

\section{Conclusion}

Analyzing the interviews, we can see the important nodes in the family and career path factors which can affect the effectiveness of and equal opportunities for students with disabilities. Summarizing the nodes, we can outline the following which can be used in the rest of the study.

In the question of the problem and the subsequent period, the most important nodes are the underlying circumstances of the problem and the circumstances under which the attitude of the environment to the studies and the success of the child have changed and whether the child received the appropriate development after recognizing the problem. Subsequently, it is important for students to be informed about their situation and what attitudes they may experience.

In the dimension of motivation, it is worth examining how the family, friends and teachers affect the individual. In the case of career guidance, the student's environment may try to influence the student's decision with suggestions and, in such cases, how much the individual's interest and abilities are taken into account. It is important whether they motivate them even if they are not sure or if they do not apply for a higher education institution. All this is linked to the path of the individual's inner motivations and how they assess their abilities, and whether they consider them to be a promoting or limiting factor.

How the students are doing in different educational institutions can depend on whether they request help from other students, educators and helping organizations. In this case, an important factor is whether the individuals are aware of the available and request able help. It is particularly prominent that the forms of assistance that worked in previous educational level are less effective in higher education. As a result of this, students perceive being left alone with their learning difficulties that have an impact on their motivation and achievement. In addition to external assistance, students also have a strategy to facilitate their own lives and effectiveness, as well as their relationship to learning.

The most important of the nodes of the post-completion period is their determination to complete their studies, and if they have already completed their studies, are they able to utilize their qualification in the labour market. It is also important to see how their learning plans appear in their future plans.

So we got the following answers to our research questions: 
We received the following answer to our first question. There are a number of elements in the practice of promoting equal opportunities for higher education that can help the students with available services. However, their availability and efficiency are less effective than in public education, therefore there are significant obstacles for these students to get access to information about helping services, who they can talk about their difficulties, and from whom they can ask for help, Moreover there are significant differences in the attitude of professionals and teachers towards students with disabilities and their difficulties.

The answer to our second question is, therefore, that these difficulties have a particular impact on study success and motivation.

The answer to our third question is that the aspirations for equal opportunities in higher education have no effect on the career choices of the students concerned, because the interviews showed that the students had no prior information about what services they could use at the university and how these services could help their studies.

\section{Further possibilities of research:}

The topic can be studied from the point of view of disabled students, as well as from the perspective of co-ordinators and equal opportunities workers working in higher education, which can make the results of questioning students with disabilities in a more subtle way:

- To examine the methods of the employees of higher education organizations that assist disabled students, their views on the effectiveness of their work in the field of equal opportunities, and which types of disabilities are the cases, to what extent and in which circumstances students can be granted the requested service, and in which cases the students most typically require assistance.

- For non-specific students, the purpose of the research is to investigate how information on equal opportunity is accessed by students with disabilities and how receptive they are for disabled students and how they think they can help disabled students.

\section{References}

1. Andrásné Teleki Judit (2009): Fogyatékossággal élő hallgatók a felsőoktatásban Tájékoztató, Oktatási és Kulturális Minisztérium, Budapest http://www.nefmi.gov.hu/letolt/felsoo/felsoo_fogytaj_090213.pdf letöltés dátuma: 2017.10.03.

2. Attewell, P., Lavin, D., Domina, T. és Levey, T. (2007): Passing the torch: Does higher education for the disadvantaged pay off across the generations? Russell Sage Foundation, New York. 
3. Bánfalvy Csaba (2014): Fogyatékos személyek diplomával, Gyógypedagógiai szemle, 42. 4: 249-267.

4. Bódi Emese és Garai Orsolya (2011): Előnyben részesítés a felsőoktatási felvételi eljárásban. Felsőoktatási Mühely, 5. 1:71-80.

5. Csányi Yvonne (2007): Helyi adatgyüjtés a sajátos nevelési igényü gyermekek körében egy OECD-projekt keretében. Új pedagógiai szemle, 57. 7-8: 56-67.

6. Dávid Mária (2015): Speciális igényüek a felsőoktatásban és a felnőttképzésben. Eszterházy Károly Főiskola, Eger.

7. Fenyves Veronika, Bácsné Bába Éva, Szabóné Szőke Réka, Kocsis Imre, Juhász Csaba, Máté Endre és Pusztai Gabriella (2017): Kísérlet a lemorzsolódás mértékének és okainak megragadására a Debreceni Egyetem Gazdaságtudományi Kar példáján, Neveléstudomány: oktatás-kutatásinnováció, 5. 3: 5-14. https://bit.ly/2I94SP3, Letöltés dátuma: 2018.07.24.

8. Fogyatékosságügyi statisztikák Szöveggyüjtemény (2009): 2001. évi népszámlálás 12. A fogyatékos emberek helyzete. Eötvös Loránd Tudományegyetem Bárczi Gusztáv Gyógypedagógiai Kar, Budapest.

9. Fuller, M., Bradley, A. és Healey, M. (2004): Incorporating disabled students within an inclusive higher education environment. Disability and Society, 19. 5: 455-468.

10. Gordosné Szabó Anna (2004): Bevezető: általános gyógypedagógiai ismeretek. Nemzeti Tankönyvkiadó, Budapest.

11. Harper, S. R. és Quaye, S. J. (2009): Student Engagement in Higher Education. Routledge, New York-London.

12. Holloway, S. (2001): The Experience of Higher Education from the Perspective of Disabled Students. Disability and Society, 16. 4: 597-615.

13. Kálmán Zsófia és Könczei György (2002): A Taigetosztól az esélyegyenlőségig, Osiris Kiadó, Budapest.

14. Kiss László (2014): Fogyatékkal élő és krónikus beteg hallgatók a felsőoktatásban. Felsőoktatási Mühely, 8. 1: 117-128.

15. Könczei György, Laki Ildikó, Füzesi Zsuzsanna, Szabó Laura (2016): Virtuális kerekasztal-beszélgetés az egészségproblémából fakadó akadályozottság témájában. In: Németh Zsolt (szerk.) Mikrocenzus 2016. 1. A 2016. évi mikrocenzus témakörei - Háttértanulmányok a mikrocenzus programjáról és témaköreiről, Központi Statisztikai Hivatal, Budapest.

16. Laki Ildikó (2017): A magyarországi nagyothallók társadalma In: Torgyik Judit (szerk.) Válogatott tanulmányok a társadalomtudományok köréből. Konferencia helye, ideje: Párkány, Szlovákia, 2017.06.12-2017.06.13. International Research Institute, Komárno.

17. Laki Ildikó (2015): A felsőoktatás hallgatói - a fogyatékossággal élő hallgatók felsőfokú tanulmányai. In Karlovitz J. (szerk.): Fejlődő jogrendszer és gazdasági környezet a változó társadalomban, International Research Institute, Komárno.

18. Mesterházi Zsuzsa - Gereben Ferencné (2006): A (gyógy)pedagógiai munkát segítő alapfogalmak. In: Zsoldos Márta (szerk.): (Gyógy) pedagógiai diagnosztika és tanácsadás. Kézikönyv a nevelési tanácsadókban, szakértői és rehabilitációs bizottságokban végzett komplex vizsgálatokhoz. OM Fogyatékos gyermekek, Tanulók Felzárkóztatása Közalapítvány, Budapest. 
19. Pusztai Gabriella (2011): A láthatatlan kezektől a baráti kezekig. Új mandátum kiadó, Budapest.

20. Pusztai Gabriella és Szabó Diána (2014): Felsőoktatási hallgatók és fogyatékossággal élő társaik. Kapocs, 13. 4: 23-36.

21. Riddell, S., Tinklin, T. és Wilson, A. (2005): Disabled Students in Higher Education. Perspectives on widening access and changing policy. Routledge, London.

22. Vida Gergő (2017): Miként lesz a tanulási zavar diagnózisa stigma - Avagy mi a fontosabb: a diagnózis vagy a gyermek? Új pedagógiai szemle, 67. 3-4: 16-33.

23. Tausz Katalin, Bácskay Andrea, Csordás Gábor, Kovács Beáta, Németh Eszter, Panyik Barbara, Tóth Judit Nikoletta (2015): 2011. évi népszámlálás 17. a fogyatékossággal élők helyzete és szociális ellátásuk, Központi Statisztikai Hivatal, Budapest.

24. Tőzsér Zoltán: A „,nem-tradicionális” hallgató. A nemzetközi szakirodalom tanulságai, Iskolakultúra, 22. 1-2: 89-94.

Törvényi hivatkozások, adatbázisok

1. IESA - A hallgatói eredményességre gyakorolt intézményi hatás a felsőoktatásban (2013-2016), Pusztai Gabriella.

2. Oktatásügyi Minisztérium (29/2002. V. 17.): OM-rendelet a fogyatékossággal élő hallgatók tanulmányainak folytatásához szükséges esélyegyenlőséget biztosító feltételekről.

3. 2011. évi CXC törvény a nemzeti köznevelésről.

4. 2011. évi CCIV. Törvény a nemzeti felsőoktatásról. 